\title{
Resectable Osteosarcoma
}

National Cancer Institute

\section{Source}

National Cancer Institute. Resectable Osteosarcoma. NCI Thesaurus. Code C162661.

Osteosarcoma that is amenable to surgical resection. 